\title{
TO SEE ONESELF THROUGH THE EYES OF OTHERS AND THROUGH THE EYES OF BOOKS: PERSPECTIVE IN BOHUMIL HRABAL'S AUTOBIOGRAPHICAL TEXTS
}

Keywords: Bohumil Hrabal, autobiography, autofiction, perspective, identity

Słowa kluczowe: Bohumil Hrabal, autobiografia, autofikcja, perspektywa, tożsamość

Almost all works by the Czech writer Bohumil Hrabal feature a multi-layered play with perspective; Hrabal tends to confront diverse views, connect incomparable things, employ techniques of collage and montage in order to set meaning in motion, and to look at himself through the eyes of others. This article focuses primarily on Hrabal's autobiographical texts (the In-House Weddings trilogy and his late "journalistic texts" from The Magic Flute onwards), in which the play with perspective becomes one of the key principles of the writer's poetics, although other texts by Hrabal will also be considered. I will largely concentrate on perspective in its broader sense, that is, as a certain worldview that is linked to the overall semantics of the work and is completed by the reader in the process of reception. Nevertheless, I will also demonstrate that a vital aspect of the representation of this worldview is Hrabal's playful use of focalization.

Hrabal's reminiscent trilogy In-House Weddings, Vita Nuova, and Gaps ${ }^{1}$ has an untraditional form: each book amounts to an original experiment with structure, punctuation, genre, and, above all, narrative perspective (focalization). Hrabal assigns the narrative voice to his wife Eliška Plevová, nicknamed Pipsi. Eliška is the narrator of the whole trilogy, yet the events are focalized not only from her perspective but also from the perspective of Hrabal as a character

\footnotetext{
${ }^{1}$ Hrabal wrote the In-House Weddings trilogy in 1982. Originally, it was a 700-page-long, compact manuscript which Hrabal divided into three sections; he worked on them until 1985. For the complicated history of the genesis of the whole trilogy, see Bohumil Hrabal, Svatby v domě (Praha: Pražská imaginace, 1995), 565-571.
} 
in the narrative and the other characters. This complex perspective structure results in Bakhtinian polyphony, where the crucial part occurs in the clash of various perspectives. Experiments with focalization as well as other levels of meaning represent not only a play with the genre of autobiography or autofiction, ${ }^{2}$ but also an exploration of human identity. Indeed, in many of his texts Hrabal asks, "Who am I?" and repeatedly confesses that for him writing means endless inquiring about himself. ${ }^{3}$ Hrabal's writings about himself raise the following questions: What can we learn about ourselves when we look at ourselves through the eyes of others? How is our self-concept shaped by conscious and unconscious components of the human psyche and what role do convention and culture play in this process? And, finally, what is the relationship between our identity and time? I will now examine these questions in more detail.

\section{To see oneself through the eyes of others}

Leaving behind the perspective of "I" allows Hrabal to gain distance from himself and to reveal facts about himself that might prove difficult to express from the first-person perspective. Using Eliška's perspective helps Hrabal to own up to some difficult moments in his life: he brings up his own failures, fears, etc. in a self-ironical manner devoid of pathos. Eliška's perspective thus represents an inversion of the prevalent tendency in autobiographical writing, that is, the writer's smoothing out his or her life story and avoiding unpleasant and dissonant events, such as failures, weaknesses, embarrassing moments, or wrongdoings. Eliška's perspective knocks Hrabal off the pedestal as a revered writer by deconstructing the conventional, medially, and culturally formed image of Bohumil Hrabal: "Everyone thought my husband was a happy person that a husband like mine must make me the envy of every woman that life with my husband must be nothing but fun and games But it was something else entirely."

${ }^{2}$ The term autofiction is used in miscellaneous meanings (see Wolf Wucherpfennig, "Autobiographisches Schreiben und Identitätsarbeit: 10 Thesen," in Autobiographisches Schreiben in der deutschsprachigen Gegenwartsliteratur: Entwicklungen, Kontexte, Grenzgänge, Band 3, ed. Michael Grote, Beatrice Sandberg (München: Iudicum Verlag, 2009), 272-279). I use it for reminiscent narratives that blur the boundary between factuality and fictionality and are distinctly self-reflexive.

${ }^{3}$ Bohumil Hrabal, Pirouettes on a Postage Stamp: an Interview Novel with Questions Asked and Answers Recorded by László Szigeti, trans. David Short (Prague: Karolinum Press, 2014), 72.

${ }^{4}$ Hrabal, Vita Nuova, trans. Tony Liman (Evanston, Illinois: Northwestern University Press, 2010), 87. Hrabal himself reveals his intention to write an autobiography that would be an inversion of the eulogical biographies of Tolstoy, Picasso, or Dostoyevsky, in which women praise their husbands: "I concluded that I'd let my wife do the talking back-to-front. Part 1 [In-House Weddings] is written and I've just finished Part 2 [Vita Nuova], where my wife talks about me, but she's inclined to keep knocking me and showing up my negative sides. Male affectations are something awful!" (Hrabal, Pirouettes on a Postage Stamp, 85). 
Eliška often complains about her husband and her difficult life as his wife; she points to the dissonance between the way Hrabal appears on the outside or the way he speaks about himself on the one hand, and on the other the way he truly is, for example with regard to gardening or cooking: "And my husband had a reputation as an excellent cook but I knew better... he found a way to ruin whatever he made he managed to burn everything because while he cooked he liked to read or pop down to the pub [...]." ${ }^{5}$ These numerous passages bear a sense of the grotesque or anecdote, but in other moments of Eliška's narration darker sides of Hrabal's life emerge, such as auto-censorship, or other concessions to the Communist authorities. Particularly auto-censorship was a very sensitive topic to Hrabal: to be able to publish he often adjusted the language of his texts and deleted controversial passages; sometimes he even rewrote whole scenes, thus changing their meaning. ${ }^{6}$ These adjustments started as early as with Hrabal's first volume of short stories from the 1950s (The Lark on a String), whose print was cancelled, but they also occur in texts from the normalisation period (1968-1989), such as Krasosmutnění [Beautiful Sadness], which was an ideologically acceptable version of The Little Town Where Time Stood Still, or Kluby poezie [Clubs of Poetry], which is a collage of texts from Too Loud a Solitude and Něžný barbar [The Gentle Barbarian]. ${ }^{7}$

Hrabal conforms to ideological pressure and gets published even at the price of compromises; paradoxically, though, even these adjusted texts are able to exert a powerful aesthetic effect on the reader, as the great popularity of his first books of short stories from the 1960s proves. While a literary historian's judgement of Hrabal's interventions in the original texts may be indulgent, this is not the case with Eliška's narrative - she condemns Hrabal's compromises, for she can see that he is losing himself because of them:

In vain I tried to cheer him up in vain I tried to tell him they were the fools and not him in vain I warned him to leave his text as he'd originally written it and although I hadn't read any of it myself that wasn't the point the point was for him to be true to himself and not start writing the way editors wanted him to write but my husband just wouldn't listen [...] I started to see my husband as a bit of a coward as someone prepared to say one thing to his friends and quite another to the editorial board... I couldn't stand that two-faced world that two-faced perspective those two-faced conversations and I listened to my husband with distaste and always said exactly what I thought $[\ldots]{ }^{8}$

\footnotetext{
${ }^{5}$ Hrabal, Vita Nuova, 89.
}

${ }^{6}$ Apart from Vita Nuova and Gaps, Hrabal discusses his own auto-censorship interventions in Hrabal, Total Fears, trans. James Naughton (Prague: Twisted Spoon Press, 1998), 177-178.

${ }^{7}$ Hrabal wrote Něžný barbar, a book of memories about his friend, painter and graphic artist Vladimír Boudník, in 1973; it has not been translated into English.

${ }^{8}$ Hrabal, Vita Nuova, 202. 
Eliška's view is as sharp as a surgeon's scalpel, calling a spade a spade (I will add more details on this in the next section), but it also expresses her worries about Hrabal betraying his own ideals.

In the subsequent scene, in which Hrabal again oscillates between concessions and himself but finally plucks up the courage to choose himself and loses his job as a result, Eliška says: "I smiled at my husband and said... Look if you want I'll be the provider forget about Larks on a String forget about everything just write what it is you want to write and I'll worry about the money..." Furthermore, Eliška confronts Hrabal's concessions and compromises with her fate of a post-war German affected by the stigma of collective guilt; ${ }^{10}$ her narration of her own past constitutes a counterpoint to Hrabal's fearful attitude and demonstrates that one can maintain one's dignity and personal integrity even in the face of pressure from the authorities.

The perspective of the other thus allows Hrabal to catch a glimpse of those areas of his own personality that Ego often conceals via defence mechanisms, marginalizes, or represses: Hrabal touches upon his wrongdoings, failures, and fears (he accounts for these fears by invoking his genes and a prenatal experience of a life-threatening situation). ${ }^{11}$ By making Eliška the narrator, Hrabal can expose this part of himself while keeping a safe distance from it: he can talk about it without becoming too absorbed in it. This effect results not only from the distance that an external perspective provides but also from the way Eliška discusses Hrabal's failures or fear: she usually uses irony or sarcasm, sometimes she presents them in the form of farce, grotesque, or a tall tale a la Hašek, sometimes she belittles her husband's perspective by confronting it with another view or life attitude. This happens, for example, in a long scene in which Hrabal feels despondent about his current hospitalization: Eliška alternates depictions of his self-pitying, depressive moods with images from the cheerful life of the wheelchair users Lothar and Pavlík. ${ }^{12}$

We have observed that Hrabal makes use of Eliška's point of view to contemplate his darker sides. However, the perspective of the other also enables him to step outside one's fear, that is, to deprive it of its power and to see oneself

\footnotetext{
${ }^{9}$ Ibid., 205.

${ }^{10}$ Ibid., 202.

${ }^{11}$ Hrabal makes an extraordinarily powerful and intensive confession of his fears in Total Fears, 156-193. Here he also provides an explanation - in the form of an anecdote documenting his prenatal trauma: "[O]ne Sunday, when I was still in my mother's womb, my impetuous grandpa dragged my mother out into the yard just before lunch, with me still inside her, he pulled out a gun and roared... Kneel, I'm going to shoot! And my mother, a grown-up little girl, clasped her hands and begged for me... Finally my grandmother came out and said... Come in and eat, or it'll all get cold. So in we went to eat [...] and here I am... but that fear stayed with me, felt through the womb of my mother..." (Hrabal, Total Fears, 158-159).

${ }^{12}$ Hrabal, Svatby v domě, 518-548.
} 
and the world in a different light. Eliška's view resemanticizes experiencing itself; a tension between her perspective and the perspective of the character of Hrabal arises. This clash between diverse worldviews proves crucial in Hrabal's writings about himself. All of the perspectives in which Hrabal is viewed from the outside as a character (mostly via Eliška's narration, but also his mother's) appear in the context of his own internal perspective, mediated either by Eliška (focalization through the character of Hrabal) or in direct speech. Taking into account the fact that we are dealing with the autobiographical (or autofictional) genre rather than with pure fiction (e.g. a novel), this polyphony can be related to the author himself. These miscellaneous perspectives can be regarded as different voices that meet in the person behind the text: identity, the subject, is displayed in motion, as a stream of various perspectives and modes of experiencing reality. Through his play with perspectives Hrabal unveils the asubjective, pulsating, open nature of human identity. Importantly, this alternation of views or experiencing modes is firmly anchored in time, as I will show in the next section. ${ }^{13}$

\section{Temporal confrontation of views}

The previous section has demonstrated that the perspective of the other allows Hrabal to discuss sensitive topics concerning his own life and, at the same time, to create a counterposition to his own self-understanding. Furthermore, the play with perspectives reveals perspectivization as such: by linking sundry aspects of experiencing the world into one textual stream, Hrabal shows how views of the same reality can be motivated by different modes of experiencing reality - shaped by individual mental predispositions as well as by cultural determinants. ${ }^{14}$ In the In-House Weddings trilogy, a clash of perspectives related to temporal experiencing of the world proves especially significant.

Numerous points in this trilogy display a confrontation of diverse ways of temporal experiencing of reality, of which the clash of a memory with the present outlook is particularly conspicuous. Incidentally, as in many other texts, Hrabal explicitly thematizes remembering here: "My husband's past revisited him in installments Out of nowhere he suddenly perked up and shouted The arbor!

${ }^{13}$ Josef Fulka also deals with the view of the other in Hrabal's work. He explains the role that this view plays in creating the characters' identity or self-concept. Fulka discusses the effect of the view of the other on two levels - the level of the Hegelian struggle for recognition and the erotic level. See Josef Fulka, "Dívat se buzarem: pohled u Bohumila Hrabala," Slovo a smysl, no. 21 (2014), $178-192$.

${ }^{14}$ I will discuss the cultural semiotic formation of the world in Hrabal's texts in the following section. 
The arbor! Darling an image just came to me of that arbor in Židenice [...]."15 Moreover, he often refers to Novalis and his idea that "we have our memories, the second now."16

Hrabal's autobiographical texts often stage the clash of a viewpoint tinged with a memory or melancholy with a matter-of-fact outlook, devoid of any illusion or sentiment. In one scene in In-House Weddings, Hrabal has brought Eliška to the brewery where he spent his childhood. His view of the brewery is shaped by his childlike enchantment - he tells Eliška enthusiastically about the beautiful trees, the garden, etc.; Eliška's perspective, however, is different: she describes the components of a wrecked car instead of a garden and she can only see a few scrub trees where Hrabal is talking about an avenue of fruit trees. Within a single paragraph, several instances of such conflicting information occur, gradating in an encounter with the porter, who disregards Hrabal's excitement over meeting a figure from "his best years" and throws the couple out of the property while offering his perspective on the past: he evokes a modest accommodation as opposed to the luxury of Hrabal's family living in four rooms. ${ }^{17}$

The textual Hrabal's view of the brewery through the eyes of memory is therefore exposed to a twofold threat and to the merciless demands of the Freudian reality principle: first through Eliška's "realistic" description of the brewery area, then in the encounter with the porter, whom Hrabal still sees through the eyes of a child; in the second case, however, it is not just a view but a real blow of the reality of life. It is striking that Hrabal at first refuses to leave the child perspective behind and his outlook only changes after several confrontations; accepting the present goes hand in hand with disillusion: "And so we went out the brewery gates, my fiancé shaking with shame, I knew he would never set foot in there again, and why should he?" 18 The whole scene ends with Eliška's inner monologue about a similar experience that she went through herself when she visited the villa from which she had been expelled after WWII. In Eliška's monologue, all in one sentence, the situation recurs where the Freudian principle of daydreaming or escape is defeated by the demands of reality. Countless other scenes depicting a similar disillusion occur in Hrabal's works: for example, in the reminiscent prose The Little Town Where Time Stood Still, little Hrabal orders a tattoo of a little boat with an anchor, yet instead he finds a full-breasted bearded mermaid on his chest. ${ }^{19}$

\footnotetext{
${ }^{15}$ Hrabal, Vita Nuova, 101.

${ }^{16}$ Hrabal, Pirouettes on a Postage Stamp, 156.

${ }^{17}$ Hrabal, In-House Weddings, 141-143.

${ }^{18}$ Ibid., 143.

${ }^{19}$ Hrabal, The Little Town Where Time Stood Still, 149.
} 
As I have already mentioned, Eliška also reports about her past. For example, she repeatedly recounts her traumatic experience of a German afflicted with the stigma of a collective responsibility or of losing self-confidence after her husband-to-be ran away just before the wedding, but her narration shows that this difficult past has already been processed and closed. By contrast, remembering as represented by the character of Hrabal takes the form of reliving and re-immersion: while Hrabal returns to his past, Eliška talks about it from a distance. Considering, once again, the self that stands behind the text, or is created by the act of writing itself, two general principles of relating to one's past emerge here - principles that exist in one single person and, metaphorically speaking, dispute in every human being. ${ }^{20}$

As has become obvious, Eliška's perspective is predominantly matter-of-fact, anchored in the present moment or the "reality principle." Eliška can see things that her husband denies, and depicts reality unadorned; at the same time, she remarks ironically on Hrabal's flights from reality, which take the form of the aforementioned returns to the past but also of actual physical escapes. ${ }^{21}$ Eliška's perspective adds to Hrabal's view of himself not only the Freudian reality principle, but also the ability to approach oneself with self-irony and not so seriously. As I have shown, painfulness is balanced not just by another point of view but also by elements of the grotesque or by an anecdote. For instance, Hrabal incorporates a grotesque tale about a duck whose throat was not cut properly into the narrative of his disillusioning return to the brewery. Switching between perspectives and experiencing modes, being overwhelmed by the world's oppressive painfulness or cruelty in one moment and viewing the world with childlike awe and enchantment in the next, seeing oneself alternately from the perspective of self and from the perspective of the other: Hrabal's multifaceted play with perspective not only raises the question of identity but also draws attention to perspective as such. Perspective, which in our everyday experiencing of the world rarely stands out as an object of contemplation but in which we are always already moored - not unlike an eye that is looking but cannot see itself. To use the language of phenomenology: in Hrabal's narrative, the appearance as such manifests itself; what gets foregrounded is the

${ }^{20}$ This twofold attitude to one's past, combining distance and reliving, appears in other reminiscent texts by Hrabal. Hrabal formulates this duality in the following way: "Now, when I can take a rare look at myself from above, when I am simultaneously the gazing sphinx and the object she is fixing her strict eyes on [...]" [Hrabal, Kdo jsem (Praha: Pražská imaginace, 1995), 270; my translation].

${ }^{21}$ Hrabal, Vita Nuova, 87. Elsewhere Hrabal writes: "My own impression is that things I write - thanks to my untidiness and lack of endurance--the things I write are half-baked. It's really my readers who have to construct them, or cook them at home, in their heads." Hrabal, Pirouettes on a Postage Stamp, 95. 
noetic act (noesis), in which the object is only just being formed. ${ }^{22}$ Other factors contribute to this process of shaping the world, as I will demonstrate in the next section.

\section{To see the world through the eyes of books}

Hrabal's texts thus explore the process of "seeing" or "producing" reality; they do so not only by means of experimental techniques that activate the reader, offering her or him the text as a challenge or a "semi-finished product" (in his preface to Vita Nuova, for instance, Hrabal explicitly calls for the reader's contribution $^{23}$ ), but also by frequent references to literature, the arts, and cultural images. Many of Hrabal's texts include both direct and figurative depictions of the way arts and literature mould and transform our worldview. With a slight overstatement, one could state that Hrabal's work amounts to an imaginative illustration of the hermeneutical notion that "the text is the medium through which we understand ourselves." ${ }^{24}$ In the novel Too Loud a Solitude, this play with ways of viewing reality appears in condensed form: the narrator, Haňta, views the world through the eyes of the books he has read; the philosophers Laozi, Kant, Schopenhauer, Erasmus of Rotterdam, and others enter his world - he leads a dialogue with them. He claims that he no longer knows which ideas are his own and which are borrowed; he repeatedly says, "I am a jug filled with water both magic and plain; I have only to lean over and a stream of beautiful thoughts flows out of me." 25 The concluding metaphor of a gigantic press ruining Prague as well as Haňta's suicide in the press logically follow from the activity that Haňta is forced to do (i.e. destroying books): if we are destroying books, hence culture, we are destroying ourselves.

In his autobiographical texts, Hrabal views himself through the eyes of books. This becomes evident in his play with the genre of In-House Weddings, whose Czech edition appeared with the subtitle "dívčí románek," meaning a romance for girls. This categorization largely governs the plot of the whole text, yet Hrabal also transgresses and parodies the genre. Yes, Eliška recounts how she and Hrabal first met, their first dates, she repeatedly refers to her earlier romantic disappointment, and the book ends with a wedding. However,

${ }^{22}$ Edmund Husserl, Ideas Pertaining to a Pure Phenomenology and to a Phenomenological Philosophy. First book, trans. Fred Kersten (The Hague: Martinus Nijhoff Publishers, 1983), 205-207.

${ }^{23}$ Hrabal, Vita Nuova, 3-4.

${ }^{24}$ Paul Ricoeur, "The Hermeneutical Function of Distanciation," in Paul Ricoeur, Hermeneutics and the Human Sciences, ed. and trans. John B. Thompson (New York: Cambridge University Press 1995), 142.

${ }^{25}$ Hrabal, Too Loud a Solitude, trans. Michael Henry Heim (London: Abacus, 1993), 1. 
Hrabal is certainly no Prince Charming: as discussed above, Eliška depicts his recurring "escapes" and human weaknesses. Hrabal also plays with genre conventions in his memories of Vladimír Boudník in The Gentle Barbarian, adopting his narration to the genre of the grotesque; the title of the second part of the trilogy, then, contains an intertextual link to Dante's lyrical love poetry (and partial autobiography) La Vita Nuova. The last part, Gaps, contrasts with the preceding two books in the trilogy in that it shows the life story in fragments, short textual segments, in which indeterminacy and the sphere of not knowing play a significant role. Via these and other formal experiments (with the structure of the text, punctuation, focalization, etc.), the trilogy challenges conventional notions of autobiography and blurs the boundary between reality and fiction, and thus indirectly points to the role of genre, literary, and cultural conventions in writing about oneself.

The cultural coding of reality becomes particularly prominent in Hrabal's late "journalistic" texts. When discussing contemporary political events, describing his mental and physical states, or narrating about his cats, he always, over and over, makes use of countless literary images, intercultural allusions and references. In the first of these texts, The Magic Flute from January 1989, he writes about Czechoslovakia: "The Gods have deserted this land, the heroes of antiquity have departed, Hercules and Prometheus..."; ${ }^{26}$ he links his own contemplations of suicide with references to the suicide of the Czech poet Konstantin Biebl, to Arthur Schopenhauer's father, and to Seneca; ${ }^{27}$ he refers to the addressee of his texts-letters, Ms. April, as the mythological Ariadne and to himself as Theseus; ${ }^{28}$ he names his tomcat Cassius Clay after the well-known American boxer $;{ }^{29}$ he says that Václav Havel has recreated the myths of Socrates and Prometheus, ${ }^{30}$ and so on.

This tendency to code or to see reality through the eyes of books and artistic and cultural images even leads Hrabal to modify reality in his autobiographical and journalistic texts: he adds invented events and mystifications (similarly as Jaroslav Hašek) with the aim of presenting an aesthetically powerful image. In The Magic Flute, he narrates a rather morbid tale of a youngster who was setting swans on fire at a German lake:

[A]nd when they caught him, he was a young man, who said in his defence, that he was inspired by Salvador Dali, a painting of a burning giraffe had disturbed him so much at night that it made the room hurt, where he dreamt about this blazing giraffe and Salvador Dali's paranoiac-critical

\footnotetext{
${ }^{26}$ Hrabal, Total Fears, 14.

${ }^{27}$ Ibid., 11.

${ }^{28}$ Ibid., 46.

${ }^{29}$ Ibid., 88, 122.

${ }^{30}$ Ibid., 54-55.
} 
method, he'd wanted to pour petrol over a giraffe at the zoo to see its mane catch fire, but he couldn't reach up that high, so he'd lured over a trusting swan, and when it soared up blazing into the sky, he saw it rise to the zenith before it fell, he saw Salvador Dali's burning giraffe. $^{31}$

Hrabal's story of Dali's burning giraffe is nevertheless fictional: the quoted passage is framed by sentences in which Hrabal first makes a general comment - "I'm made to finish imagining these images which visit me, which I heard people tell" 32 - and then explicitly acknowledges fictionalization: "I heard the story about the swan, but the stuff about the burning giraffe and the paranoiac-critical method is something I didn't just wilfully append, it's the way my mind works." ${ }^{33}$ Hrabal's imaginative completion of images is inextricably linked to his own creative method - transforming life into an artistic image, taking a certain motif, theme, or anecdote and using it for his own purposes. ${ }^{34}$

Nevertheless, I would also like to highlight another important facet of Hrabal's playful representation of ways of viewing reality: often an everyday phenomenon can become a symbol or event by means of which we suddenly break through to the secret of being - it becomes a "crack" through which we catch a glimpse of the world from an atemporal perspective and get under the surface of things. Frequently these insights concern suffering, whether that of people or of animals. In Vita Nuova, Eliška reports about Hrabal watching a children's scooter race, which, however, seen from her husband's perspective is a long way from an innocent children's game: Hrabal observes how seriously the children are taking the race and identifies among them the ambitious ones who do not hesitate to use their elbows to push away anybody standing in their way and who, later in life, are bound to assert themselves at all costs, and those who will never, ever win, and those who are going to give up even before starting. Hrabal's view transcends the horizon of the present moment and what he can see in this way fills him with immense pain and compassion: "But after those kiddie scooter races my husband wasn't even up for a sip of beer or a bite to eat he just lay there under the covers quietly moaning...."35

${ }^{31}$ Ibid., 13.

${ }^{32}$ Ibid.

${ }^{33}$ Ibid., 14.

${ }^{34}$ For a discussion of the use of fictionality in autobiographical writing, see Zuzana Fonioková, "Memory and Identity in Fiction and Autobiography: Nelly's Version by Eva Figes, Memories of a Catholic Girlhood by Mary McCarthy, and Montauk by Max Frisch," in Memory: Forgetting and Creating, ed. Wojciech Owczarski, Zofia Ziemann, and Amanda Chalupa (Gdańsk: Gdańsk University Press, 2016), 231-232.

${ }^{35}$ Hrabal, Vita Nuova, 57. Hrabal frequently uses a sports competition as a symbol or "cipher" of human existence. See his depiction of the Olympics, basketball, and tennis in "I naše chyby jsou dokonalé," "US Open 92” (Hrabal, Pojízdná zpovědnice, 74-78, 79-80). 
Hrabal's oeuvre features numerous instances of such transformation of reality into a symbol or metaphor of human existence: in Too Loud a Solitude, a rats' battle in the underground becomes an allegory of the never-ending conflicts of human history; in A Few Sentences, the world-famous horse race Grand Pardubice Race and its most difficult part, the so-called Thurn-Taxis Ditch, becomes "a cipher which I find able to enlighten for me not only human life, but the whole world... For me this Thurn-Taxis Ditch represents a boundary-situation, as Karel Jaspers taught me." ${ }^{36}$ In short, in Hrabal's texts, everyday events gain the potential of becoming a breakthrough on the way to mystical enlightenment, satori, which can arrive at any time and place. Recurring are references to Buddha's teaching of suffering and compassion, which makes its way into a considerable number of Hrabal's late texts; he repeatedly mentions Laozi, who reached the ideal of emptiness. These considerations bring us to the last topic: I will conclude this article with a short reflection on identity.

\section{4. "Tat-twam asi!" - "It is you!"}

As became clear in the preceding sections, the topic of identity is reflected in Hrabal's playful use of narrative perspectives as well as in his play with literary genres and cultural codes. Hrabal's trilogy and late texts reveal identity in its instability, as a variable stream of perspectives and modes of experiencing reality, sundry masks that Hrabal wears when looking at his life: his own perspective, his wife's and his mother's perspectives, literary genres, quotations and paraphrases of favourite writers, discontinuous fragments, banalities as well as philosophical ideas. Nonetheless, all of these voices are at the same time the writer's own voice, in whose consonance, clash, and conflict he fashions his textual "I."

And yet something deeper shows through this dance of masks: the stream itself in which the various images come and go, the rhythm of the switching modes of experience, views, and perspectives. Hrabal's writing - more strikingly than that of other authors - foregrounds the act of writing itself, which approximates an ecstatic rapture: using the "alla prima" method, he lets his images spurt out of him onto the paper; ${ }^{37}$ the textual stream finds its own ways and enters hidden corners of the mind, the subconscious, one association provokes another,

\footnotetext{
${ }^{36}$ Hrabal, Total Fears, 64.

${ }^{37}$ Hrabal's "alla prima" writing method is closely linked to his writing technique - he wrote or, rather, churned out his texts on a typewriter and usually produced them on one sitting or within a very short period (for example, he wrote the novel I Served the King of England in eighteen days). He likened his writing to that of Jack Kerouac as well as to Jackson Pollock's action painting. See also Hrabal, Pirouettes on a Postage Stamp, 68, 114-115, 132-133.
} 
or else the outpouring of images stops and three dots indicate that not everything can be translated into words and that reality will always remain elusive. In this massive textual stream (in Vita Nuova Hrabal even dispenses with punctuation so that it does not hinder the flow of his images), the self manifests itself, the self in constant flux: the burdensome experiencing mode changes in a flash through Eliška's ironical comments, the arrival of a cherished cat, or a gag story.

Switching positions quickly, not sticking to one perspective but viewing himself through the eyes of others and through the eyes of books, Hrabal exposes identity as a continuous stream of creating, decomposing, and constant refiguring of oneself. His self, in its instability and lack of attachment to any single perspective or experiencing mode, comes very close to Eastern thinking that points to the fictionality of a substantial, fixed self. Hrabal himself often acknowledges drawing inspiration from Eastern philosophies, which have left a clearly visible trace in his works. ${ }^{38}$ However, this view of identity also leans on phenomenological hermeneutics, which regards the self as being subject to continuous change, permanently undergoing refiguration as it encounters the Other - whether in the form of other people or texts. In fact, this ceaseless transformation also underlies narrative identity, which reflects these changes in time.$^{39}$ Hrabal's playful use of perspectives and masks (diverse forms of self-concepts) precisely mirrors this variability and openness. Contemporary cognitive approaches in the theory of autobiography also consider human identity in its instability and non-substantiality: as Eakin says about Mary Karr's memoir The Liars' Club: "she is the music of her narrative while the music lasts." 40

Yet another dimension can be detected in Hrabal's play with identity: the recurring experience, performed in the text, when the author's self becomes someone else, a blank sheet on which the world of others leaves its imprints. “"Tat-twam asi!' - 'It is you!'” - Hrabal repeatedly refers to this sentence from

${ }^{38}$ Hrabal's inspiration from Buddhism and Taoism becomes clear not only from the topics his texts deal with and his frequent quotations of Buddha's and Laozi's ideas, but also from his discussions of it in many commentaries and interviews (see, e.g., Hrabal, Pirouettes on a Postage Stamp, 72, 104). Hrabal learned about Eastern thinking second-hand: it was mediated to him primarily by reading Schopenhauer and Eliot (Josef Zumr, "Ideová inspirace Bohumila Hrabala," in Hrabaliana, ed. Milan Jankovič, Josef Zumr (Praha: Prostor 1990), 25) and in interviews with the Czech poet and philosopher Egon Bondy. Moreover, he reread Laozi's Canonical Book of Virtues (Tao Te Ching) every year: "That's my annual Rite of Spring, including the thunder of April..." (Hrabal, Pirouettes on a Postage Stamp, 53-54).

${ }^{39}$ Paul Ricoeur, Oneself as Another (Chicago: The University of Chicago Press, 1992), 113-115.

${ }^{40}$ Paul John Eakin, Living Autobiographically. How we Create Identity in Narrative (Ithaca and London: Cornell University Press 2008), 78. Here Eakin draws on the neurologist Antonio Damasio and his metaphor (borrowed from T. S. Eliot) "You are the music while the music lasts," which Damasio uses to explicate the process of forming self-consciousness. Eakin takes up Damasio's findings to introduce a new conception of identity and autobiographical writing in general (see Eakin, 60-86). 
the Upanishads, enacting it through his poetic images and original poetics. ${ }^{41}$ His writing method of a recording clerk or "undiscriminating attention" brings together all aspects of reality, philosophical contemplations as well as pub anecdotes; vitality meets the ideal of emptiness, enchantment with life meets anguish, yet always one conditions the other, as Hrabal learned from Laozi: "being at rock-bottom and gazing upwards." 42

\section{Sum mary}

This study analyses the use of perspective in the autobiographical trilogy (In-House Weddings, Vita Nuova and Gaps) and the late "journalistic" texts by the Czech writer Bohumil Hrabal. The article examines Hrabal's play with perspective on several levels: on the narrative level, Hrabal experiments with the narrative voice and focalization, and views himself through the eyes of his wife Eliška, who is also the narrator of the whole trilogy; this strategy allows him to gain distance from the "I-perspective" and to touch upon sensitive moments of his life (particularly auto-censorship, his relationship with the Communist authorities, and various fears). Furthermore, Eliška's view clashes with the view of Hrabal as a character in the narrative world, which results in an original autobiographical polyphony; the article presents a detailed scrutiny of these perspectives with regard to time. Drawing from hermeneutics as a way of self-understanding shaped by texts and culture, the analysis of perspectivity will demonstrate that Hrabal also views himself through the eyes of books and cultural images; additionally, the article points to parallels with Hrabal's other works, particularly Too Loud a Solitude. Finally, Hrabal's playful use of perspective concerns the question of identity: the textual self that appears in the stream of images manifests itself in constant motion, thus unveiling the non-substantiality and openness of human identity. In this way, Hrabal's writing about himself approximates the view of self in Eastern philosophies (esp. Buddhism and Taoism - Hrabal's sources of inspiration) as well as contemporary cognitive approaches to the theory of autobiography (Paul John Eakin).

\section{PRZEGLADAĆ SIE W INNYCH I W KSIAZZZKACH: PUNKT WIDZENIA W PROZIE AUTOBIOGRAFICZNEJ BOHUMILA HRABALA}

\section{Streszczenie}

Artykuł analizuje problem punktu widzenia w trylogii autobiograficznej Bohumila Hrabala (Wesela w domu, Vita nuova, Przerwy w zabudowie) oraz jego późnych „dziennikarskich” tekstach. Hrabalowskie gry z perspektywą rozpatrywane są na kilku poziomach: na poziomie narracji pisarz eksperymentuje z głosem i fokalizacją, patrząc na siebie samego oczami swojej żony, Eliški, która jest

41 "When something awful happens somewhere in the world I even take it as if it was something I'd done, or something done to me. All those great massacres, everything that happens, it's me. That's what Schopenhauer taught me, and he was taught by Indian philosophy ['tat-twam asi' - it is you]. I see people shooting each other in the back, in war, the innocent ones, and that's me. And even the cat, the killed cat, that's me. If I see a dog that's been run over, that's me; or that profound fellow-feeling" (Hrabal, Pirouettes on a Postage Stamp, 81; I have added words that are missing from the English translation in the square brackets). See further Hrabal, Kdo jsem, 222.

${ }^{42}$ Hrabal, Pirouettes on a Postage Stamp, 118. 
narratorką całej trylogii. Ta strategia pozwala mu na dystans od perspektywy „ja” i omówienie kontrowersyjnych punktów swojej biografii (problemu autocenzury, stosunku do władzy komunistycznej i różnych lęków). Ponadto punkt widzenia Eliški ściera się z punktem widzenia Hrabala jako bohatera, co skutkuje oryginalną autobiograficzną polifonią; $w$ artykule te ścierające się punkty widzenia są analizowane $\mathrm{z}$ wykorzystaniem kategorii czasu. W nawiązaniu do hermeneutyki jako metody samorozumienia analiza Hrabalowskiego perspektywizmu pokazuje też, jak widział on siebie poprzez książki i obrazy kulturowe. Analiza ta odwołuje się również do innych utworów pisarza, m.in. Zbyt głośnej samotności. Hrabala gra z perspektywą łączy się z problemem tożsamości: tekstowe „ja” objawia się poprzez strumień obrazów i pozostaje w ciągłym ruchu, odsłaniając niesubstancjalny i niedokonany aspekt ludzkiej tożsamości. W ten sposób Hrabalowskie pisanie o sobie nawiązuje do filozofii Wschodu (buddyzmu i taozimu, ważnych dla pisarza) oraz współczesnych kognistywistycznych ujęć teorii autobiografii (Paul John Eakin). 